Original

\title{
Involvement of phosphodiesterase 4 in $\beta$-adrenoceptor agonist-induced amylase release in parotid acinar cells
}

\author{
Keitaro Satoh ${ }^{1)}$, Ming-Yu Guo ${ }^{1)}$ and Nakayasu Sairenji ${ }^{2)}$ \\ ${ }^{1)}$ Department of Physiology, Nihon University School of Dentistry at Matsudo, Matsudo, Japan \\ ${ }^{2)}$ Department of Anesthesiology, Nihon University School of Dentistry at Matsudo, Matsudo, Japan
}

(Received 26 December 2008 and accepted 15 January 2009)

\begin{abstract}
Adrenoceptor activation increases intracellular cAMP levels and consequently induces exocytotic amylase release in parotid acinar cells. Phosphodiesterase (PDE) catalyses the hydrolysis of cAMP, which terminates the downstream signaling of this second messenger. We investigated the involvement of PDE4, a cAMP-PDE, in $\beta$-adrenoceptor agonistinduced amylase release in mouse, rat and rabbit parotid acinar cells by using the specific PDE4 inhibitor rolipram. cAMP-PDE activity was detected in mouse, rat and rabbit parotid acinar cells. In the presence of rolipram, cAMP-PDE activity was reduced by about $31 \%, 38 \%$ and $33 \%$ in mouse, rat and rabbit parotid acinar cells, respectively. The increase in cAMP levels induced by the $\beta$-adrenoceptor agonist isoproterenol was enhanced in the presence of rolipram in mouse, rat and rabbit parotid acinar cells. Isoproterenol-induced amylase release, but not constitutive amylase release, was also enhanced in the presence of rolipram in mouse, rat and rabbit parotid acinar cells. These results suggest that the rolipram-sensitive cAMP-PDE, PDE4, is involved in $\beta$-adrenoceptor agonist-induced amylase release in parotid acinar cells. (J Oral Sci 51, 173-179, 2009)
\end{abstract}

Keywords: phosphodiesterase; rolipram; amylase release; cAMP; parotid acinar cells.

Correspondence to Dr. Keitaro Satoh, Department of Physiology, Nihon University School of Dentistry at Matsudo, 2-870-1 Sakaecho-nishi, Matsudo, Chiba 271-8587, Japan

Tel: +81-47-360-9326

Fax: +81-47-360-9327

E-mail: satoh.keitaro@nihon-u.ac.jp

\section{Introduction}

Cyclic adenosine-3', 5' -monophosphate (cAMP) is an intracellular signal molecule involved in a wide variety of cellular functions (1). The intracellular cAMP level is regulated by adenylate cyclase and cyclic nucleotide phosphodiesterase (PDE), which are the enzymes responsible for the synthesis and breakdown of cAMP, respectively (2).

PDE catalyses the hydrolysis of cAMP, which terminates the downstream signaling of this second messenger. PDE has been classified into 11 families on the basis of substrate and inhibitor specificities, allosteric properties and amino acid sequences (3-5). Among the PDE families, 8 have been reported to hydrolyze cAMP: $\mathrm{Ca}^{2+} /$ calmodulin-dependent PDE (PDE1), cGMP-stimulated PDE (PDE2), cGMPinhibited PDE (PDE3), cGMP-insensitive PDE (PDE4), rolipram-insensitive PDE (PDE7), rolipram and 3-isobutyl1-methylxanthine-insensitive PDE (PDE8), and the recently recognized PDE10 and PDE11 (3-5).

Exocytosis is the process by which cells release the contents of their secretory granules. This process is continuous in most cells (constitutive exocytosis), but it can be greatly accelerated by appropriate cellular signals such as neural stimulation (regulatory exocytosis). In parotid acinar cells, stimulation of $\beta$-adrenoceptors increases the intracellular cAMP level, and consequently induces exocytotic release of amylase $(6,7)$.

Rolipram has been shown to be a potent cAMP-PDE inhibitor, and was originally developed as a possible antidepressant agent $(3,4,8,9)$. PDE4, the rolipram-sensitive cAMP-PDE, is known to be present in rat parotid gland (10), but its cellular function is still unclear. Here we investigated the role of PDE4 in amylase release from 
isolated parotid acinar cells.

\section{Materials and Methods \\ Materials \\ Collagenase A, bovine serum albumin (BSA) and} Protease Inhibitor Cocktail (Complete ${ }^{\mathrm{TM}}$ ) were purchased from Roche (Basal, Switzerland). Trypsin (type III), trypsin inhibitor (type I-S), isoproterenol, rolipram, and Crotalus atrox snake venom were obtained from Sigma (St. Louis, MO, USA). Calmodulin and AG 50W-X4 resin (200 - 400 mesh; hydrogen form) were obtained from Wako (Osaka, Japan) and Bio-Rad (Hercules, CA, USA), respectively. $\left[8-{ }^{3} \mathrm{H}\right] \mathrm{cAMP}(1187.7 \mathrm{GBq} / \mathrm{mmol})$ was obtained from Perkin-Elmer (Wellesley, MA, USA). An cAMP enzyme immunoassay kit was purchased from Amersham (Piscataway, NJ, USA).

\section{Preparation of parotid acinar cells}

Acinar cells from the parotid glands of male ddy mice, Sprague-Dawley rats $(200-250 \mathrm{~g})$ and Japanese white rabbits $(2-2.5 \mathrm{~kg})$ were prepared as described previously (11). The parotid glands were removed and placed in a small volume with Krebs-Ringer-bicarbonate (KRB) solution of the following composition (in $\mathrm{mM}$ ): $\mathrm{NaCl}, 116 ; \mathrm{KCl}, 5.4$; $\mathrm{MgSO}_{4}, 0.8 ; \mathrm{CaCl}_{2}, 1.8 ; \mathrm{NaH}_{2} \mathrm{PO}_{4}, 0.96 ; \mathrm{NaHCO}_{3}, 25$; HEPES (pH 7.4), 5; and glucose 11.1. The KRB solution was equilibrated in an atmosphere of $95 \% \mathrm{O}_{2} / 5 \% \mathrm{CO}_{2}$. After mincing with a razor, the glands were treated with KRB buffer with $0.5 \%$ BSA in the presence or absence of enzyme. First, the glands were incubated with trypsin $(0.5$ $\mathrm{mg} / \mathrm{ml}$ ) at $37^{\circ} \mathrm{C}$ for $10 \mathrm{~min}$. After incubation, the trypsintreated glands were removed by centrifugation at $200 \times g$ for $1 \mathrm{~min}$. The glands were subsequently incubated in $\mathrm{Ca}^{2+}-\mathrm{Mg}^{2+}$-free $\mathrm{KRB}$ solution containing 1 mM EGTA and trypsin inhibitor $(0.5 \mathrm{mg} / \mathrm{ml})$ at $37^{\circ} \mathrm{C}$ for $5 \mathrm{~min}$. After the solution had been removed by centrifugation $(200 \times g$ for $1 \mathrm{~min}$ ), the glands were incubated in $\mathrm{Ca}^{2+}{ }_{-} \mathrm{Mg}^{2+}$-free $\mathrm{KRB}$ solution without trypsin inhibitor at $37^{\circ} \mathrm{C}$ for $5 \mathrm{~min}$. After removal of the solution by centrifugation $(200 \times g$ for $1 \mathrm{~min})$, the glands were incubated in KRB solution with collagenase $(1.5 \mathrm{mg} / \mathrm{ml})$ at $37^{\circ} \mathrm{C}$ for $20 \mathrm{~min}$. The suspension was passed through eight layers of nylon mesh to separate the dispersed cells from undigested connective tissue, and was gently put on KRB solution containing 4\% BSA. After centrifugation ( $50 \times g$ for $5 \mathrm{~min}$ ), the cells were suspended in appropriate amounts of KRB solution containing $0.5 \%$ BSA and $0.02 \%$ trypsin inhibitor. All experimental protocols were approved by the Laboratory Animal Committee of the Nihon University School of Dentistry at Matsudo.

\section{Amylase release}

The dispersed acinar cells from a rabbit, a rat or three mice were suspended in $28 \mathrm{ml}$ of KRB solution containing $0.5 \%$ BSA and $0.02 \%$ trypsin inhibitor and incubated at $37^{\circ} \mathrm{C}$ with the indicated agents. The cell suspension was separated into 4 parts $(7 \mathrm{ml}$ each), and incubated with vehicle, rolipram $(50 \mu \mathrm{M})$, isoproterenol $(1 \mu \mathrm{M})$, or rolipram/isoproterenol. Isoproterenol was added after preincubation with vehicle or rolipram for $10 \mathrm{~min}$. After incubation times of $0,5,10$ and $15 \mathrm{~min}, 1 \mathrm{ml}$ of cell suspension was removed and passed through filter paper. Amylase activity in the filtrates was measured according to Bernfeld (12). Total amylase activities were measured in acinar cells homogenized in $20 \mathrm{mM}$ phosphate buffer (pH 6.9) containing $0.01 \%$ Triton X-100.

\section{Measurement of the intracellular cAMP level}

The dispersed acinar cells from a rabbit, a rat or three mice were suspended in $8 \mathrm{ml}$ of KRB solution containing $0.5 \%$ BSA and $0.02 \%$ trypsin inhibitor and incubated at $37^{\circ} \mathrm{C}$ with the indicated agents. The cell suspension was separated into 4 parts $(2 \mathrm{ml}$ each), and incubated with vehicle, rolipram $(50 \mu \mathrm{M})$, isoproterenol $(1 \mu \mathrm{M})$, or rolipram/isoproterenol. Isoproterenol was added after preincubation with vehicle or rolipram for $10 \mathrm{~min}$. After incubation times of $0,0.5,1,2,3,5$ and $10 \mathrm{~min}, 200 \mu \mathrm{l}$ of cell suspension was taken, mixed with $30 \mu \mathrm{l}$ of $35 \%$ perchloric acid, and put on ice for $30 \mathrm{~min}$. After addition of $60 \mu \mathrm{l}$ of $17.5 \%$ potassium hydroxide to the mixture for neutralization, the mixture was centrifuged at $10,000 \times g$ for $5 \mathrm{~min}$, and the supernatant was isolated. The cAMP concentration in the supernatant was measured using an enzyme immunoassay kit.

\section{Assay of PDE activity}

Parotid acinar cells were homogenized with $10 \mathrm{ml}$ of $20 \mathrm{mM}$ Tris- $\mathrm{HCl}$ (pH 7.4) containing $2 \mathrm{mM} \mathrm{MgCl}_{2}, 1 \mathrm{mM}$ dithiothreitol (DTT), $1 \mathrm{mM}$ phenylmethylsulfonyl fluoride (PMSF), $1.3 \mathrm{mM}$ benzamidine, and Protease Inhibitor Cocktail $\left(\right.$ Complete $\left.{ }^{\mathrm{TM}}\right)$ and centrifuged at $1,000 \times g$ for 10 min at $4^{\circ} \mathrm{C}$. The supernatant was used for assay of PDE activity. cAMP-PDE activity was determined by the twostep method (13). The enzymatic reaction was performed in a total volume of $0.1 \mathrm{ml}$. The reaction mixture contained $50 \mathrm{mM}$ Tris- $\mathrm{HCl}$ (pH 7.4), $5 \mathrm{mM} \mathrm{MgCl} 2,1 \mathrm{mM} \mathrm{CaCl}_{2}$, $0.4 \mu \mathrm{M}$ calmodulin, and the substrate $\left(0.1 \mu \mathrm{M}\left[{ }^{3} \mathrm{H}\right] \mathrm{cAMP}\right.$; $3.7 \mathrm{kBq}$ ) and enzyme. The mixture was incubated at $30^{\circ} \mathrm{C}$ for $10 \mathrm{~min}$, and then the reaction was terminated by heating at $90^{\circ} \mathrm{C}$ for $\left.5 \mathrm{~min} .{ }^{3} \mathrm{H}\right] 5^{\prime}$-AMP formed by PDE was converted to $\left[{ }^{3} \mathrm{H}\right]$ adenosine by the action of nucleotidase ( $25 \mu \mathrm{l}$ of $1 \mathrm{mg} / \mathrm{ml}$ snake venom at $30^{\circ} \mathrm{C}$ for $10 \mathrm{~min}$ ). The 
reaction was terminated by adding $0.5 \mathrm{ml}$ of water and the denatured protein was removed by centrifugation $(10,000$ $\times g, 3 \mathrm{~min})$. The clear supernatant fluid $(0.5 \mathrm{ml})$ was applied to a 0.5 -ml column of AG 50W-X4 resin (200-400 mesh; hydrogen form). The reaction product, $\left[{ }^{3} \mathrm{H}\right]$ adenosine, was eluted with $1.5 \mathrm{ml}$ of $3 \mathrm{~N}$ ammonium hydroxide after washing the column with $15 \mathrm{ml}$ of water, and radioactivity was measured using a liquid scintillation counter.

\section{Protein quantification}

Protein concentrations were determined by the method described previously (14) with a BSA standard

\section{Statistical analysis}

Significance of differences was determined using Student's $t$-test. The level of statistical significance was taken as $P<0.05$.

\section{Results \\ PDE4 activity in parotid acinar cells}

We determined cAMP-PDE activity in mouse, rat and rabbit parotid acinar cells (Fig. 1). The specific activity of cAMP-PDE in mouse parotid acinar cells was lower than those in rat and rabbit cells. Next, we examined the effect of rolipram, a specific inhibitor of PDE4, on the cAMPPDE activity. Rolipram $(50 \mu \mathrm{M})$ inhibited cAMP-PDE activities to $30.6 \%, 37.9 \%$ and $32.6 \%$ of the control in mouse, rat and rabbit parotid acinar cells, respectively (Fig. 1). These results suggest that about $60-70 \%$ of cAMP-PDE in mouse, rat and rabbit parotid acinar cells is PDE4.

\section{Effect of rolipram on isoproterenol-induced cAMP elevation in parotid acinar cells}

We studied the effect of rolipram on cAMP elevation stimulated by $\beta$-adrenoceptor activation in mouse (Fig. 2A), rat (Fig. 2B) and rabbit (Fig. 2C) parotid acinar cells. The $\beta$-adrenoceptor agonist isoproterenol $(1 \mu \mathrm{M})$ invariably increased cAMP levels in the absence of rolipram (Fig. 2, left column). The basal and isoproterenol-induced cAMP levels in rabbit parotid acinar cells were higher than those in mouse and rat. In the case of preincubation with rolipram $(50 \mu \mathrm{M})$ for $10 \mathrm{~min}$, isoproterenol-induced cAMP elevation was robustly enhanced (Fig. 2, right column). These results suggest that PDE4 is involved in regulation of the intracellular cAMP level induced by $\beta$-adrenoceptor activation in parotid acinar cells.

\section{Effect of rolipram on isoproterenol-induced} amylase release in parotid acinar cells

We next examined the effect of rolipram on amylase

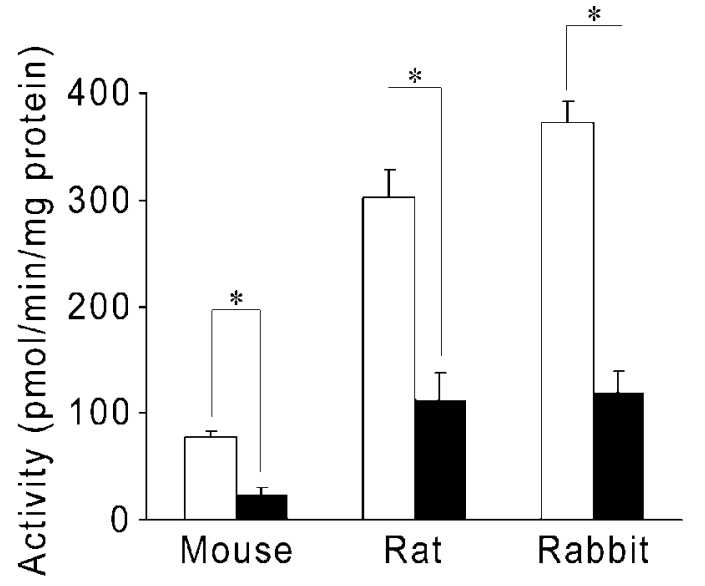

Fig. 1 Effect of rolipram on cAMP-PDE activity in acinar cells isolated from mouse, rat and rabbit parotid glands. cAMP-PDE activities in parotid acinar cells were assayed in the absence (clear column) or presence (solid column) of rolipram $(50 \mu \mathrm{M})$. Results are means \pm S.E.M. from three independent experiments. Statistical analysis: $*, P<$ 0.05 .

release induced by isoproterenol in mouse (Fig. 3A), rat (Fig. 3B) and rabbit (Fig. 3C) parotid acinar cells. Isoproterenol $(1 \mu \mathrm{M})$ induced amylase release timedependently, and isoproterenol-induced amylase release was enhanced by preincubation with rolipram $(50 \mu \mathrm{M})$ for 10 min compared with controls. Rolipram had no effect on constitutive amylase release. These observations suggest that PDE4 is involved in isoproterenol-induced amylase release in parotid acinar cells.

\section{Comparison of cAMP elevation and amylase} release in parotid acinar cells

In parotid acinar cells, isoproterenol stimulates amylase release via an increase in the intracellular cAMP level $(6,7)$. We compared the effects of rolipram on isoproterenolinduced cAMP elevation and amylase release in mouse, rat and rabbit parotid acinar cells (Fig. 4). Rolipram increased isoproterenol-induced cAMP levels about 9.9-, 2.7- and 7.2-fold (Fig. 4A), whereas this inhibitor enhanced isoproterenol-induced amylase release about 1.6-, 1.5and 1.8-fold in mouse, rat and rabbit parotid acinar cells, respectively (Fig. 4B), indicating that the increase in cAMP levels is not linearly correlated with the enhancement of amylase release. 

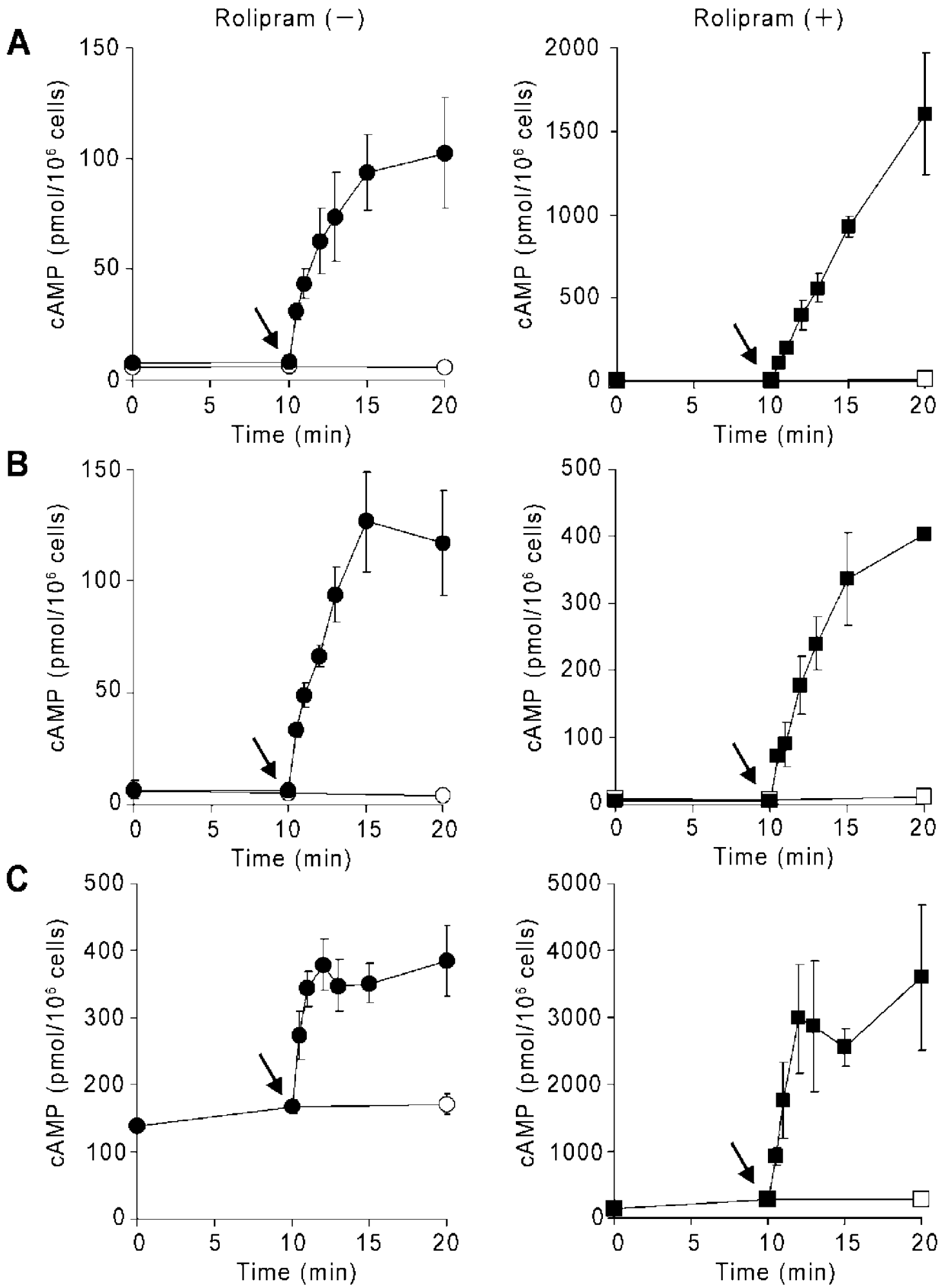

Fig. 2 Effect of rolipram on the isoproterenol-induced increase in cAMP levels in acinar cells isolated from mouse, rat and rabbit parotid glands. After preincubation without (clear and solid circles) or with (clear and solid squares) rolipram $(50 \mu \mathrm{M})$ for $10 \mathrm{~min}$, cells were stimulated with vehicle (clear circles and squares) or $1 \mu \mathrm{M}$ isoproterenol (solid circles and squares), as indicated by the arrow. A, mouse; B, rat; C, rabbit. Results are means \pm S.E.M. from three independent experiments. 

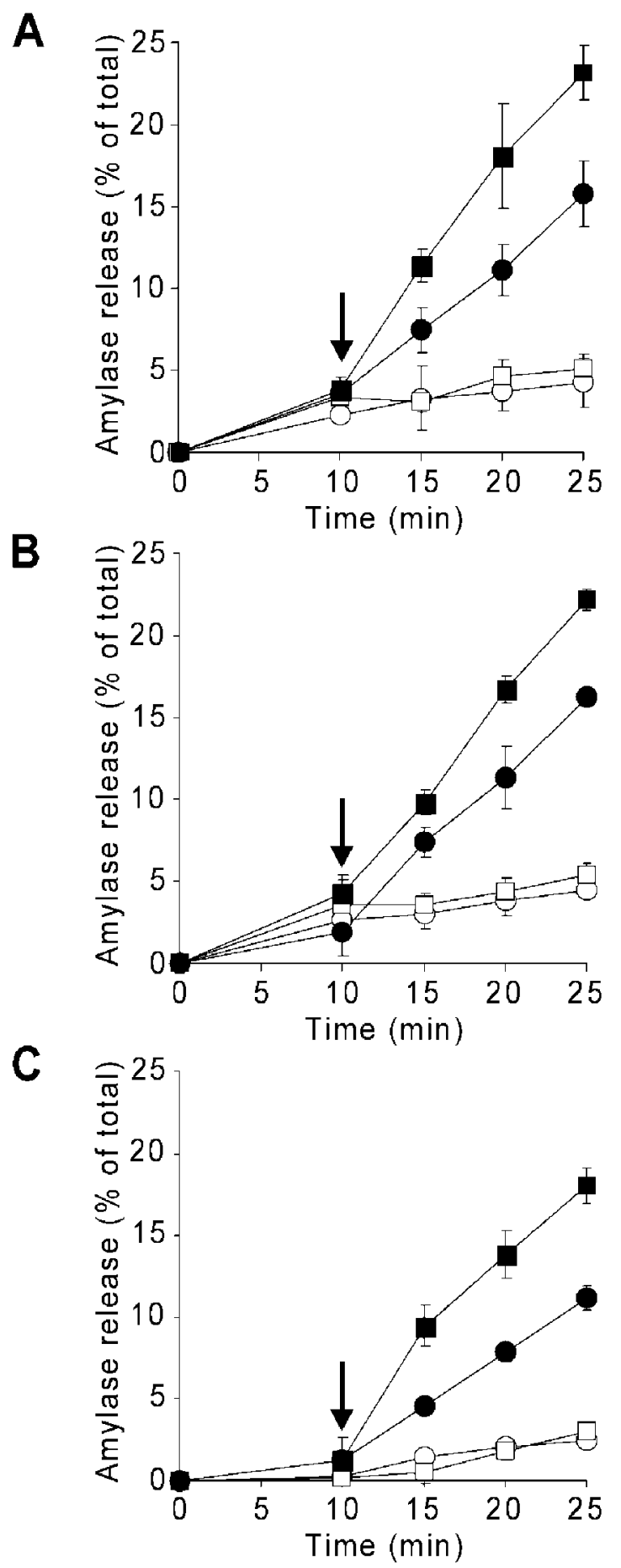

Fig. 3 Effect of rolipram on isoproterenol-induced amylase release in acinar cells isolated from mouse, rat and rabbit parotid glands. After preincubation without (clear and solid circles) or with (clear and solid squares) rolipram (50 $\mu \mathrm{M})$ for $10 \mathrm{~min}$, cells were stimulated with vehicle (clear circles and square) or $1 \mu \mathrm{M}$ isoproterenol (solid circles and squares) as indicated by the arrow. Amylase release was expressed as a percentage of the total. Results are means \pm S.E.M. from three independent experiments.

\section{Discussion}

Various PDE isozymes have been reported to be present in the parotid glands of rodents (15). In this study, we demonstrated involvement of PDE4 in amylase release induced by $\beta$-adrenoceptor activation in acinar cells isolated from mouse, rat and rabbit parotid glands. Although the specific activities of cAMP-PDE were different, the inhibitory effect of the PDE4 specific inhibitor rolipram on the activities was comparable, being about $60-70 \%$. These results imply that PDE4 plays a dominant role in the regulation of cAMP breakdown in parotid acinar cells. In fact, $\beta$-adrenoceptor agonist-induced cAMP formation was drastically enhanced in the presence of rolipram.

In the presence of rolipram, $\beta$-adrenoceptor agonistinduced amylase release was enhanced 1.5-1.8-fold in mouse, rat and rabbit parotid acinar cells, but constitutive release was not affected. It has been reported that exocytosis comprises both constitutive and regulatory exocytosis (7). Therefore, these observations suggest that PDE4 contributes to regulatory amylase release but not to constitutive release.

The enhancement of amylase release by rolipram was not linearly correlated with the increase in cAMP levels. This observation implies the existence of a maximum level of cAMP-dependent amylase release in parotid acinar cells. In parotid acinar cells, cAMP-dependent protein kinase (PKA) is activated by the cAMP levels induced by $\beta$-adrenoceptor activation, which provokes phosphorylation of many proteins (6). It has been reported that vesicleassociated membrane protein 2 (VAMP2) is essential for cAMP-dependent amylase release and that VAMP2 may be activated by PKA activation (16,17). Rab3D and Rab27, small molecular GTP-binding proteins, are also reportedly expressed in secretory granules containing amylase, and are suggested to contribute to amylase release via regulation of the size of secretory granules and maintenance of the cytoskeleton, respectively, in $\beta$-adrenoceptor agoniststimulated parotid acinar cells (18-22). Such proteins, which function downstream of the increase in cAMP levels induced by $\beta$-adrenoceptor activation, appear to regulate the maximum levels of cAMP-dependent amylase release, although the precise mechanisms are still obscure.

The PDE4 family represents the largest PDE family, being constituted by 4 genes (PDE4A, PDE4B, PDE4C and PDE4D). These four PDE4 genes generate over 20 different variants by means of alternative start sites and alternative splicing (3-5). Expression of the PDE4 family members has been reported in various tissues and cell types. Multiple different targeting molecules reactive with PDE4 family members, such as myomegalin, arrestins and A-kinase anchoring proteins, have also been identified (23-26). Furthermore, it has been demonstrated that the 

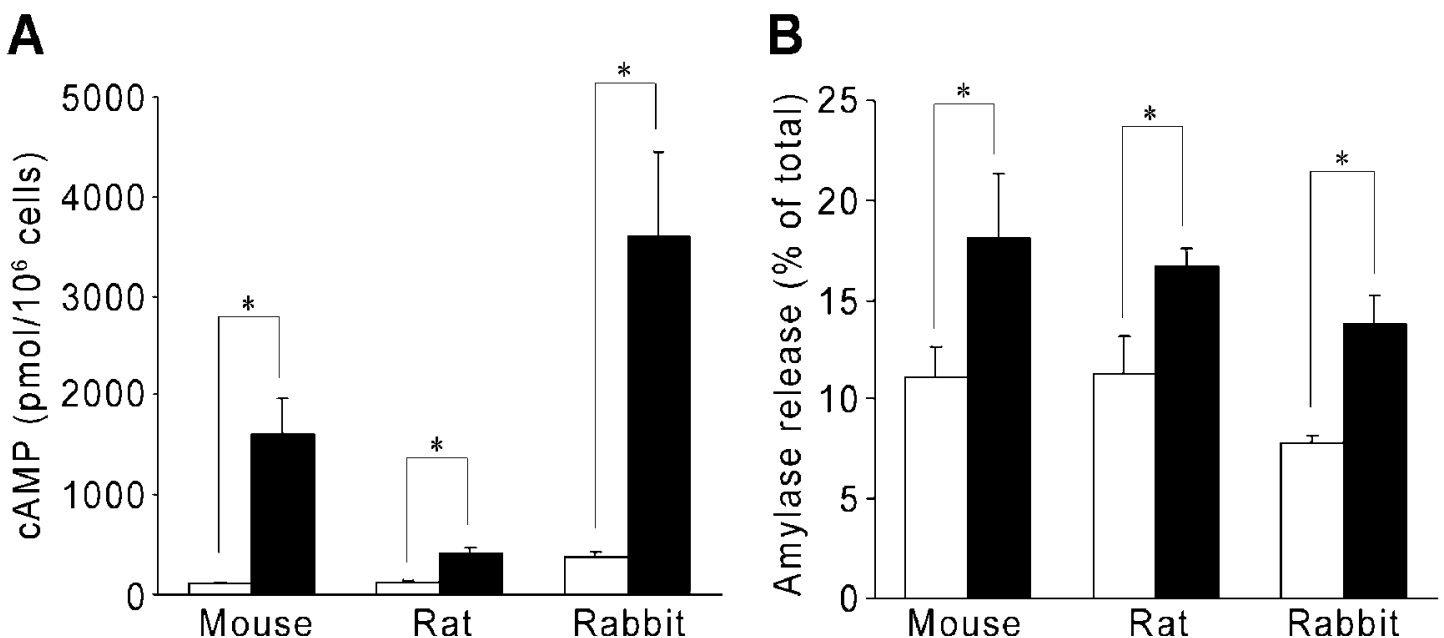

Fig. 4 Comparison of cAMP elevation and amylase release. Effects of rolipram on intracellular cAMP levels (A) or amylase release (B) in mouse, rat and rabbit parotid acinar cells stimulated by isoproterenol for $10 \mathrm{~min}$. Clear column, without rolipram; solid column, with rolipram. Results are means \pm S.E.M. from three independent experiments. Statistical analysis: ${ }^{*}, P<0.05$.

subcellular distribution of the PDE4 family is correlated with their function $(27,28)$. Therefore, further studies of the PDE4 family and its subcellular distribution in parotid acinar cells are warranted.

In conclusion, the rolipram-sensitive cAMP-PDE, PDE4, is present in mouse, rat and rabbit parotid acinar cells, where it regulates intracellular cAMP levels and is involved in $\beta$-adrenoceptor agonist-induced amylase release.

\section{Acknowledgments}

We wish to thank Prof. Hiroshi Sugiya for helpful advice and discussion.

\section{Reference}

1. Soderling SH, Beavo JA (2000) Regulation of cAMP and cGMP signaling: new phosphodiesterases and new functions. Curr Opin Cell Biol 12, 174-179.

2. Newton RP, Smith CJ (2004) Cyclic nucleotide. Phytochemistry 65, 2423-2437.

3. Bender AT, Beavo JA (2006) Cyclic nucleotide phosphodiesterases: molecular regulation to clinical use. Pharmacol Rev 58, 488-520.

4. Lugnier C (2006) Cyclic nucleotide phosphodiesterase (PDE) superfamily: a new target for the development of specific therapeutic agents. Pharmacol Ther 109, 366-398.

5. Omori K, Kotera J (2007) Overview of PDEs and their regulation. Circ Res 100, 309-327.

6. Quissell DO, Watson E, Dowd FJ (1992) Signal transduction mechanisms involved in salivary gland regulated exocytosis. Crit Rev Oral Biol Med 3, 83-107.

7. Turner RJ, Sugiya H (2002) Understanding salivary fluid and protein secretion. Oral Dis 8, 3-11.

8. Schwabe U, Miyake M, Ohga Y, Daly JW (1976) 4-(3-Cyclopentyloxy-4-methoxyphenyl)-2pyrrolidone (ZK 62711): a potent inhibitor of adenosine cyclic 3,5-monophosphate phosphodiesterases in homogenates and tissue slices from rat brain. Mol Pharmacol 12, 900-910.

9. Wachtel H (1982) Characteristic behavioral alterations in rats induced by rolipram and other selective adenosine cyclic 3',5'-monophosphate phosphodiesterase inhibitors. Psychopharmacology (Berl) 77, 309-316.

10. Imai A, Nashida T, Shimomura H (1995) Characterization of cyclic AMP phosphodiesterase isozymes in rat parotid gland. Arch Oral Biol 40, 165-168.

11. Sairenji N, Satoh K, Sugiya H (2006) $\mathrm{Ca}^{2+} /$ calmodulin-dependent cyclic nucleotide phosphodiesterase in cGMP metabolism in rabbit parotid acinar cells. Biomed Res 27, 37-44.

12. Bernfeld P (1955) Amylase $\alpha$ and $\beta$. Method Enzymol 1, 149-158.

13. Hidaka H, Asano T (1976) Platelet cyclic 3':5'nucleotide phosphodiesterase released by thrombin and calcium ionophore. J Biol Chem 251, 75087516.

14. Bradford MM (1976) A rapid and sensitive method 
for the quantitation of microgram quantities of protein utilizing the principle of protein-dye binding. Anal Biochem 72, 248-254.

15. Imai A, Nashida T, Shimomura H (1999) Comparison of phosphodiesterase isozymes in rodent parotid glands. Comp Biochem Physiol B Biochem Mol Biol 124, 397-403.

16. Fujita-Yoshigaki J, Dohke Y, Hara-Yokoyama M, Kamata Y, Kozaki S, Furuyama S, Sugiya H (1996) Vesicle-associated membrane protein 2 is essential for cAMP-regulated exocytosis in rat parotid acinar cells. The inhibition of cAMP-dependent amylase release by botulinum neurotoxin B. J Biol Chem 271, 13130-13134.

17. Fujita-Yoshigaki J, Dohke Y, Hara-Yokoyama M, Furuyama S, Sugiya H (1999) Presence of a complex containing vesicle-associated membrane protein 2 in rat parotid acinar cells and its disassembly upon activation of cAMP-dependent protein kinase. J Biol Chem 274, 23642-23646.

18. Raffaniello RD, Lin J, Schwimmer R, Ojakian GK (1999) Expression and localization of Rab3D in rat parotid gland. Biochim Biophys Acta 1450, 352-363.

19. Riedel D, Antonin W, Fernandez-Chacon R, Alvarez de Toledo G, Jo T, Geppert M, Valentijn JA, Valentijn K, Jamieson JD, Südhof TC, Jahn R (2002) Rab3D is not required for exocrine exocytosis but for maintenance of normally sized secretory granules. Mol Cell Biol 22, 6487-6497.

20. Imai A, Yoshie S, Nashida T, Shimomura H, Fukuda M (2004) The small GTPase Rab27B regulates amylase release from rat parotid acinar cells. J Cell Sci 117, 1945-1953.

21. Fukuda M, Imai A, Nashida T, Shimomura H (2005) Slp4-a/granuphilin-a interacts with syntaxin-2/3 in a Munc18-2-dependent manner. J Biol Chem 280, 39175-39184.

22. Imai A, Yoshie $S$, Nashida T, Shimomura H, Fukuda M (2006) Functional involvement of Noc2, a Rab27 effector, in rat parotid acinar cells. Arch Biochem Biophys 455, 127-135.

23. Verde I, Pahlke G, Salanova M, Zhang G, Wang S, Coletti D, Onuffer J, Jin SLC, Conti M (2001) Myomegalin is a novel protein of the golgi/centrosome that interacts with a cyclic nucleotide phosphodiesterase. J Biol Chem 276, 11189-11198.

24. Perry SJ, Baillie GS, Kohout TA, McPhee I, Magiera MM, Ang KL, Miller WE, McLean AJ, Conti M, Houslay MD, Lefkowitz RJ (2002) Targeting of cyclic AMP degradation to $\beta_{2}$-adrenergic receptors by $\beta$-arrestins. Science $298,834-836$.

25. Terry R, Cheung YF, Praestegaard M, Baillie GS, Huston E, Gall I, Adams DR, Houslay MD (2003) Occupancy of the catalytic site of the PDE4A4 cyclic AMP phosphodiesterase by rolipram triggers the dynamic redistribution of this specific isoform in living cells through a cyclic AMP independent process. Cell Signal 15, 955-971.

26. Wong W, Scott JD (2004) AKAP signalling complexes: focal points in space and time. Nat Rev Mol Cell Biol 5, 959-970.

27. Houslay MD, Adams DR (2003) PDE4 cAMP phosphodiesterases: modular enzymes that orchestrate signaling cross-talk, desensitization and compartmentalization. Biochem J 370, 1-18.

28. Houslay MD (2005) The long and short of vesicular smooth muscle phosphodiestarase- 4 as a putative therapeutic target. Mol Pharmacol 68, 563-567. 